\title{
ESTABLISHING THE EUROPEAN PUBLIC PROSECUTOR'S OFFICE AND SUPPRESSION OF CRIMINAL OFFENSES AGAINST THE EU FINANCIAL INTERESTS*
}

\author{
Sanja Jelisavac Trošić, PhD, Research Fellow \\ Institute of International Politics and Economics, \\ Makedonska 25, Belgrade, Serbia \\ sanja@diplomacy.bg.ac.rs
}

\author{
Jelena Kostić, PhD, Research Fellow \\ Institute of Comparative Law \\ Terazije 41, Belgrade, Serbia \\ suputjelena@yahoo.com
}

\begin{abstract}
During 2017, at the level of the European Union, two regulations of importance for the suppression of criminal offenses against the EU financial interests have been passed: Directive on the fight against fraud to the Union's financial interests by means of criminal law and Regulation implementing enhanced cooperation on the establishment of the European Public Prosecutor's Office (EPPO). The protection of these interests by the criminal substantive legislation did not encounter such resistance in the Member States as an idea of the establishment of the EPPO.
\end{abstract}

Pursuant to the provisions of Regulation implementing enhanced cooperation on the establishment of the EPPO are carried out by national delegated prosecutors, and the criminal proceedings are conducted by the courts of the Member States. The experience of the public prosecutors and judges in proceedings concerning those criminal offenses may also enhance knowledge and skills of relevance to the conduct of proceedings against perpetrators of offenses against financial interests of the Member States'.

In the paper authors are trying to point out the importance of timely and adequate sanctioning the perpetrators of the above-mentioned crimes. Consequently authors point to the advantages

This paper was created within the two projects: "Serbia in contemporary international relations: Strategic directions of development and firming the position of Serbia in international integrative processes foreign affairs, international economic, legal and security aspects", Ministry of Education and Science of the Republic of Serbia, number 179029, which is implemented in Institute of International Politics and Economics and "Serbian and European Law: Comparison and harmonization", Ministry of Education and Science of the Republic of Serbia, number 179031, which is implemented in the Institute of Comparative Law 
of establishing the European Public Prosecutor's Office in order to combat crimes that damage not only the financial interests of the European Union, but also the national financial interests. However, the concept of the European Public Prosecutor is not fully accepted, because the Regulation contains illogicalities that still make it unacceptable for member states. Therefore, in order for wider acceptance the establishment of the EPPO, it is necessary to amend these provisions of the Regulation.

Keywords: the European Public Prosecutor's Office, EU financial interests, economic crimes, perpetrators, investigations and prosecutions.

\section{INTRODUCTION}

Criminal offenses affecting the financial interests of the European Union (EU) fall into the category of economic offenses. Method of execution of such offenses is specific. Therefore, it is necessary to have special knowledge and skills for discovering them, and later for undertaking an investigation and conducting criminal proceedings. Discovering such offenses mainly involves specialized institutions, such as, for example, the European Anti-Fraud Office (OLAF). ${ }^{1}$ However, apart from the OLAF, findings of some national institutions can be very helpful in discovering such criminal offenses. In order to improve the fight against economic crimes, the Anti-fraud coordination service network (AFCOS network) has been established in the member states and also in the EU candidate countries. AFCOS network is a network of state authorities created to combat activities affecting the EU's financial interests. ${ }^{2}$

Control of the lawfulness of spending EU funds is in the competence of both, the internal audits in the public institutions of the member states and candidate countries, as well as in the competencies of their supreme audit institutions. The revenue of the European Union budget is mainly collected in the territory of the member states. The legality and regularity of their payment to the budget of the European Union is under the jurisdiction of the national (member states) tax and customs institutions. Due to the specific job a high level of specialization of employees in these institutions is necessary for the purpose of efficient and timely detection of irregularities affecting the EU budget. It should be borne in mind

1 See: Kostić, J.; Jelisavac Trošić, S., Digital Forensic Procedures of European Anti-Fraud Office and Protection of Personal Data, in: Duić D.; Petrašević, T. (eds.), EU and Comparative Law issues and challenges, Jean Monnet International Scientific Conference „Procedural aspects of EU law”, 06 and 07 April 2017, Josip Juraj Strossmayer University of Osijek, Faculty of Law Osijek, pp. 32-47

2 Art. 7. of the Regulation (EU, Euroatom) 883/2013 of the European Parliament and of the Council concerning investigations conducted by the European Anti-Fraud Office (OLAF) and repealing Regulation (EU) No 1073/1999 of the European Parliament and of the Council and Council Retulation (Euroatom) No 1074/1999, [2013] OJ L248/1. [https://eur-lex.europa.eu/legal-content/EN/ TXT/?uri=CELEX\%3A32013R0883] Accessed 14.03.2019 
that the specialization of the competent public prosecutor's offices and judicial authorities is also necessary. One aspect of such specialization is the establishment of the European Public Prosecutor's Office (EPPO). However, this process is not easy or simple. First of all, it seems that in the member states for a long time there was a position that, by the establishment of the European Public Prosecutor's Office, states in fact renounce their sovereignty in the field of criminal law, and for the state it is the hardest and the rarest to disavow. Today, it seems that it is no longer part of the state sovereignty, to the extent that it was before. ${ }^{3}$ One of the indicators of this member states attitude is the adoption of Council Regulation 2017/1939 implementing enhanced cooperation on the establishment of the European Public Prosecutor's Office. ${ }^{4}$ However, this does not mean that the concept of establishing EPPO is generally accepted, but only that there is a high level of agreement between the member states on the need for its establishment. Accordingly, in 2017, a total of sixteen countries informed the European Parliament, the Council and the Commission of the intention to participate in the EPPO establishment. Some countries are not involved in the process, while four countries have only expressed their desire to participate in the establishment of the Office. ${ }^{5}$ Nevertheless, regardless of skepticism, it seems that the establishment of such an office can improve the suppression of crimes for EU member states, which not only damage the financial interests of the EU, but also the national financial interests of the EU member states.

Due to the way of the European Union financing, by the establishment of criminal law protection of EU financial interests, the protection of the member states national financial interests is actually enhanced. With every new expansion, the question arises not only of how current member country will manage to face new challenges and risks, but how new member will face them. The European Union is financed mainly from its own resources, supplemented by other sources of reve-

3 Ćirić, J., Srbija i Evropski standardi u krivičnom pravu, in: , Ćirić, J.; Bejatović S. (eds.), Evropske integracije i međunarodna krivičnopravna saradnja, Institut za uporedno pravo, Srpsko udruženje za krivičnopravnu teoriju i praksu, Beograd, 2011-2012, pp. 23 and 24

4 Council Regulation 2017/1939 implementing enchanced cooperation on the establishment of the European Public Prosecutor's Office [2017] OJ L283/1, [https://eur-lex.europa.eu/eli/reg/2017/1939/ oj] Accessed 14.03.2019

5 Countries that have expressed their intention to participate in the establishment of the European Public Prosecutor's Office are: Belgium, Bulgaria, Cyprus, Czech Republic, Finland, France, Greece, Croatia, Lithuania, Luxembourg, Germany, Portugal, Romania, Slovakia, Slovenia and Spain. The following countries have expressed the desire to participate in the establishment of the Office: Latvia, Estonia, Austria and Italy. In addition to these countries, other countries may also be included in this cooperation under Article 328. of the Treaty on the Functioning of the European Union 
nue. ${ }^{6}$ Own resources include: 1) traditional own resources that are collected mainly from customs duties on imports from countries outside the European Union, as well as import duties for sugar (sugar levies), 2) own resources from value added tax (VAT), and 3) a percentage of each country's gross national income (GNI). ${ }^{7}$ Most of the European Union funds are spent on the member states territories. These funds finance: expenditures in the field of agriculture; rural development expenditures and related measures; structural operations expenditure for structural and cohesion fund; internal policy expenditure; foreign policy expenditure; administrative expenditure; reserves (monetary reserves, emergency reserves, reserve guarantees for the coverage of loans granted to non-member countries and assistance for accession to the European Union (pre-accession assistance). ${ }^{8}$ Due to the way in which the European Union finances, it can be said that the financial interests of the member states are also protected by criminal law protection of EU financial interests. Due to the amount of funds in question, as well as the use of complex structures, there are possibilities for fraud and other illegal activities. Therefore, we believe that the improvement of mechanisms for EU protection is of paramount importance for all member states.

\section{NOVELTIES REGARDING LEGAL PROTECTION OF EU'S FINANCIAL INTERESTS}

During 2017, at the level of the European Union, two regulations were adopted that are important for improving the protection of EU's financial interests in the area of criminal law. These are: Directive on the fight against fraud to the EU's financial interests by means of criminal law and the Regulation implementing enhanced cooperation on the establishment of the European Public Prosecutor's Office. ${ }^{9}$ However, although it does not constitute a criminal offense, it is also of

6 See: Jelisavac Trošić, S., Stojanović-Višić, B., EU Budget and Budget of Serbia: Impact on Serbia's Accession to the EU, Journal of Business Economics and Management, March-April 2018, year LXVI, Serbian Association of Economists, pp. 266-282, DOI:10.5937/EJOPRE1804266

7 Art. 2. of the Council Decision on the system of own resources of the European Union 2014/335/ EU, Euroatom, [2014] OJ L168/105. Art. 8. (1) of the above mentioned Decision stipulates that the Member States shall collect resources in its territory in accordance with the regulations which, if necessary, are adapted to the requirements of the European Union in order to fulfill the obligations. Consequently, such rules are communicated to the Commission for approval, and which shall be made available to the Commission in accordance with Art. 8. (2) of Union resources collected in the territory of the Member States

8 See: Stojanović, S., Razvoj sistema finansiranja Evropske unije, in: Ćirić, J. (ed.), 50 godina Evropske unije, Institut za uporedno pravo, Vlada Republike Srbije - Kancelarija za pridruživanje Evropskoj uniji, Beograd, 2007. p. 173

9 Directive (EU) 2017/1371 of the European Parliament and of the Council on the fight against fraud to the Union's financial interests by means of criminal law, [2017] OJ L 198/29, [http://data.europa. 
a great importance to combat irregularities affecting the EU's financial interests, which is done through the amendment to the Financial Regulation of 2018 and establishing the so-called EDES system. ${ }^{10}$ In this way, strengthens the EU regulations in the field of protection of the financial interests of the EU and member states from irregularities in public procurement proceeding.

The Directive on the fight against fraud to the EU's financial interests by means of criminal law contains minimum rules concerning the definition of criminal offenses and sanctions in order to combat fraud and other illegal activities that reflect negatively on the financial interests of the European Union. It replaced the Convention on the Protection of the European Communities' Financial Interests and its Supplementary Protocols of 1996 and 1997, which provided for the obligation for member states to provide not only criminal sanctions for persons committing crimes that affect the EU's financial interests, but also for persons who attempt to carry out such acts. ${ }^{11}$ According to the provisions of the Directive, criminal offense to the detriment of the financial interests of the European Union is considered as:

1) act in relation to the expenditures of the European Union budget, which is not related to public procurement;

2) any act or omission relating to the use and presentation of false, inaccurate or incomplete statements or documents resulting in unlawful retention of funds

eu/eli/dir/2017/1371/oj] Accessed 14.03.2019

10 Regulation (EU, Euratom) 2018/1046 of the European Parliament and of the Council on the financial rules applicable to the general budget of the Union, amending Regulations (EU) No 1296/2013, (EU) No 1301/2013, (EU) No 1303/2013, (EU) No 1304/2013, (EU) No 1309/2013, (EU) No 1316/2013, (EU) No 223/2014, (EU) No 283/2014, and Decision No 541/2014/EU and repealing Regulation (EU, Euratom) No 966/2012, [2018] OJ L 193/1, Early Detection and Exclusion System (EDES) - Panel referred to in Article 108 of the Financial Regulation. Provisions establishing an early detection and risk prevention system at the expense of the financial interests of the European Union have been made to prevent not only criminal offenses, but also other unlawful conduct that damages those interests. Under Article 105a and 106 (1) of the Financial Regulation, the Commission or other public contracting authority is obliged to exclude private entities from the European Union's program of receiving funds, whether it is a public procurement procedure or a grant award procedure, if those persons are in bankruptcy, insolvency proceedings or do not engage in business activities, if they do not pay taxes or social security contributions to employees, in the event of a serious breach of duty by such persons, such as a violation of intellectual property rights or the negotiation with other economic operators to distort free competition, if in the name of that legal person is commited crimes that can be considered financial fraud in terms of EU regulations protecting financial interests, corruption offense, participation in criminal organization, participation in money laundering, terrorism, child labor or trafficking, as well in case of serious violation of a contract concluded with the institutions of the European Union or other irregularities

11 The Convention on the protection of the European Communities financial interests, [1995] OJ C $316 / 48$ 
or assets from the EU budget, from the budgets managed by the EU or administered on behalf of the EU;

3) non-disclosure of information that violates a particular obligation, which has the same effect;

4) use of EU budget funds or assets for purposes other than those for which those funds were originally granted. ${ }^{12}$

Criminal offenses to the detriment of the financial interests of the European Union in accordance with the provisions of the Directive are also:

1) activities undertaken in relation to public procurement expenditures, if they have been committed in order to obtain unlawful material benefit for the perpetrator of the criminal offense or another person, the consequence of which is to detriment the financial interests of the EU;

2) any act or omission relating to the use or presentation of false, inaccurate or incomplete statements or documents, consisting in the misappropriation or unlawful retention of funds or assets from the Union budget, which are managed on EUs behalf;

3) failure to disclose information that violates a particular obligation, which has the same effect as the misuse of such funds or assets, for purposes other than those for which the funds have been granted, thereby damaging the financial interests of the European Union. ${ }^{13}$

Since the aforementioned activities refer to the illegal spending of the EU budget funds, determining the existence and proving such crimes requires knowledge in specific areas. Criminal acts which damages not only the national budget but also the budget of the European Union have a blanket disposition, so in order to define the elements of the criminal acts it is necessary to know both, the regulations adopted at the level of the European Union, and the national regulations regulating the field of public spending and disposal of the public property, but also accounting and financial regulations. For this reason, additional education is needed not only for persons involved in detection, but also for the prosecuting authorities and judicial authorities in order to improve knowledge in the field of economics.

Such a position also supports the fact that under criminal offenses (under the provisions of the Directive) are also considered the criminal offenses that can be committed in relation to income, which is different than income arising from

\footnotetext{
12 Art. 3, paragraph 2. (a) of the Directive on the fight against fraud to the Union's financial interests by means of criminal law

13 Article 3. paragraph 2 (b) of the Directive
} 
own resources on the basis of value added tax are also considered to be harmful to the European Union. For instance if a person takes an action or fails to perform any action in relation to the use or presentation of false, inaccurate or incomplete statements or documents, and the consequence of which is the unlawful reduction in the EU budget. ${ }^{14}$

It is important to point out that the criminal offenses against the financial interests of the European Union is also the criminal offense that is undertaken in relation to income arising from own resources on the basis of value added tax, as well as any act or omission committed in cross-border fraud schemes which refer to the use or presentation of false, inaccurate or incomplete declarations or documents relating to VAT, which result in a reduction in EU budget funds or non-disclosure of information in relation to value added tax, thereby violating a particular obligation with the same effect, as well as showing incorrect statements in relation to VAT in order to hide the non-payment or unlawful creation of the right to a VAT refund. ${ }^{15}$ Proof of such acts presupposes not only the knowledge of the regulations governing tax matters, but also the regulations governing accounting and financial operations. However, besides such knowledge, there is a need for adequate cooperation between tax authorities and prosecuting authorities at the national level as well as at the international level. This is precisely what justifies the specialization of the competent prosecuting authorities in the EU member states in the financial area. The prosecution and judicial authorities sometimes need to require the member states authorities to submit supplementary evidence, on which not only the indictment will be based, but later, in the course of the procedure, a final verdict. Also on the basis of which the damage to the European Union budget could be determined for the purpose of pronouncing adequate measures of property character.

The major novelty regarding the improvement of the mechanisms of criminal law protection of the EU's financial interests is the Council Regulation 2017/1939 implementing enhanced cooperation on the establishment of the European Public Prosecutor's Office. In addition to imposing criminal sanctions, significant for the suppression of crimes are measures that allow determining the existence of irregularities, which subsequently increases the chance that the perpetrators face adequate sanctions. Such an intent is precisely contained in the Regulation, since it not only defines the competencies of the European Public Prosecutor's Office,

14 Such act will exist even if information is not disclosed or a certain obligation is overcome, the consequences of which are the same as in the previous part, or if a person misuses the benefit obtained in a lawful manner and such behavior has a consequence for the EU budget or budgets managed in EU name. According to the Article 3. paragraph 2 (d) of the Directive

Ibid. 
but also its commitment to other bodies and institutions of the European Union, as well as to the member states and candidate countries. Some EU bodies have been active in the field of detecting and preventing cross-border crimes affecting the EU's financial interests for a number of years now. Establishing close cooperation of the Office with such bodies, in our opinion contributes to more effective proof of criminal offenses, and later to imposing criminal sanctions.

\section{EPPO'S ORIGIN, LEGAL FRAMEWORK AND ESTABLISHMENT}

The first attempt to establish the European Public Prosecutor's Office happened in the 1990s. A step towards this goal was the Corpus iuris project. However, it did not only concern the establishment of the Office, but also the establishment of European criminal law. It was, for the first time that the rules of importance for establishing the European Public Prosecutor's Office were defined. ${ }^{16}$ Some authors considered that the project was rather unrealistic, given the differences that exist in the legal systems of the member states of the European Union. ${ }^{17}$ However, it seems that such a problem has been overcome by establishing a new concept of criminal law protection of the financial interests of the European Union. Bearing in mind that these considers implementation of national legislation, both during prosecution and during trials in front of national courts. ${ }^{18}$ Concept of EPPO in this way imply specificities of member countries legal systems and also national sovereignty in criminal matters. However, in the event that the delegated public prosecutor withdraws from the investigation, if a decision is made by the Permanent Chamber, which is a collegial body of the EPPO, investigation may be undertaken. ${ }^{19}$ It is therefore possible that because of the fact that the Permanent Chamber is the body that monitors and directs investigations and prosecutions, a number of countries

16 The latest version of Corpus iuris from May 1999 is available on: [www.europa.eu/anti_fraud/documents/fwk-green-paper-corupus/corupus_juris_en.pdf] Accessed 14.03.2019

17 Hamran L.; Szabova E., European prosecutor's office-Cui bono?, New Journal of European Criminal Law, Vol. 4, Issue 1-2, 2013, pp. 41-42. See: Šuput, J. Uspostavljanje kancelarije Evropskog javnog tužioca, Evropsko zakonodavstvo, No. 52-53, 2015, p. 43

18 According to Article 13. paragraph 1, Council Regulation 2017/1939, delegated European Prosecutors, acting on behalf of the Office, shall act in their own Member States and shall have the same powers as national prosecutors in respect of investigations, prosecutions and indictments. Criminal prosecution before the national courts is prescribed by Article 36. of the Regulation

19 The Permanent Council chaired by the Chief European Prosecutor (Head of the Office) or one of his deputies or a European Prosecutor appointed as Chairman in accordance with the EPPO's internal rules of procedure. In addition, the permanent panel has two additional permanent members and decides in accordance with Article 10. paragraph 3 of the Decree on the withdrawal and rejection of the indictment, as well as the reopening of the investigation 
restrained in the establishment of the EPPO. ${ }^{20}$ In addition, it appears that the powers of the national courts in the matter of the indictment are considerably narrowed. It seems that the matters to be decided by the national court are decided by the Permanent Chamber as part of the EPPO.$^{21}$ This significantly deviates from the powers that traditionally belong to the judiciary in contemporary democracies. However, judicial review of EPPO decisions is nevertheless defined by the Regulation. Its provisions have established the division of jurisdiction of national courts and the Court of Justice of the European Union. National courts review the EPPO's procedural documents if they produce legal effect vis-à-vis third parties. They shall then act in accordance with the conditions and procedures established by national law. The same rule applies even if the EPPO fails to issue procedural acts that would have legal effect vis-à-vis third parties, although it was obliged to adopt these acts in accordance with the provisions of the Regulation. The validity of procedural acts of the EPPO, if such a question is raised before any court of the Member States, the interpretation and validity of the provisions of European Union law, the settlement of the conflict of jurisdiction between the EPPO and the competent national authorities in accordance with Article 267 of the Treaty on the Functioning of the European Union is decided by the Court of Justice of the European Union. ${ }^{22}$ Nevertheless, there is a controversial provision according to which a certain type of prior control of the decisions of the delegated public prosecutors is carried out by the institution in charge, represented in the Permanent Chamber of the EPPO. Consequently, the concept seems to remain controversial for a large number of member states, so the provisions of the Regulation in that part require amendment. The real possibility of establishing the European Public Prosecutor's Office is denoted in the provision of Article 86. of the Treaty on the Functioning of the European Union. ${ }^{23}$ According to this provision, the Council has the possibility to establish such Office after obtaining the approval of the Parliament. That provision also provided the legal basis for the adoption of Regulation 2017/1939, but the scope of application of that Regulation is limited.

20 Article 10. item 2 of the Regulation. Countries that have expressed a desire to establish cooperation in the process of establishing the EPPO, but not the readiness to cooperate are: Latvia, Estonia, Austria and Italy. Out of 28 members, eight members did not express readiness or desire in terms of establishing closer cooperation in order to establish the EPPO. These are the following countries: Denmark, Sweden, Malta, Ireland and the United Kingdom, the Netherlands and Hungary

21 Pursuant to Article 36. of the Regulation, it is stipulated that a draft decision on the indictment is decided by the Permanent Chamber within 21 days from the date of its delivery by the European Public Prosecutor. Therefore, some authors justly criticized the Proposal of the Regulation. About: Novokmet, A., The European public prosecutor's office and the judicial review of criminal prosecution, New Journal of European Criminal Law, Vol. 8, No. 3, 2017, pp. 374-402, DOI: 10.1177/2031952517729934

22 Article 42. of the Regulation

23 The Treaty on the Functioning of the European Union [2012], OJ C 326 
It applies primarily to the Member States that have expressed their intention to participate in the process of close cooperation in order to establish the European Public Prosecutor's Office. In accordance with the provisions of the Regulation, EPPO jurisdiction is exclusively limited to criminal offenses affecting the financial interests of the European Union. Therefore, its jurisdiction would be to investigate, prosecute and file charges against perpetrators of crimes that damage the financial interests of the EU, as well as to the crimes that are related to them.

This Regulation provides for a system of shared competences between the European Public Prosecutor's Office and national authorities in the suppression of criminal offenses that are detrimental to the financial interests of the European Union. In order to achieve the necessary cooperation between the EPPO and national institutions, mutual exchange of information of importance for the suppression of offenses within the competence of the Office is essentially necessary. The EPPO also performs the function of the indictment before the member states national courts, and the Regulation also defines the relation of its provisions with the national legislation of the member states that have expressed their intention to participate in the establishment of the EPPO. Under these provisions, the national law of the member state before whose court the European Public Prosecutor is acting, is applicable in the event that a matter is not defined by the Regulation. ${ }^{24}$ The national law of the member states whose delegated European prosecutor conducts the proceedings shall be applied in the event that it differs in relation to the decision contained in the Regulation. In case the solutions are contained in both regulations, the provision of the Regulation 2017/1939 shall apply. ${ }^{25}$ In this way, the Regulation is made more suitable for the interests of the member states, which are hesitative to renounce sovereignty in the criminal law area. This was an EU compromise in order to attract the rest of the member states in the process of closer cooperation.

The Regulation among other sets out the principle of loyalty, according to which the competent national bodies actively assist and support the investigations and prosecution carried out by the EPPO. ${ }^{26}$ The cooperation of responsible authorities and institutions is also of great importance in investigative procedures that are conducted in relation to crimes that endanger national financial interests.

\footnotetext{
24 Art. 1. and 4. of the Regulation implementing enchanced cooperation on the establishment of the European Public Prosecutor's Office. Kostić, J., Krivičnopravna zaštita finansijskih interesa Evropske unije, Institut za uporedno pravo, Beograd, 2018. p. 63

25 Art. 5. (3) of the Regulation

26 Art. 5. (6) of the Regulation
} 
Pursuant to the provisions of the Regulation, delegated public prosecutors are before the national courts, acting on behalf of the EPPO. With regard to the conducting an investigation, prosecution, and indictment, they have the same powers as the national prosecutors. ${ }^{27}$ This is precisely the solution which is acceptable for the EU member states.

\section{EPPO'S DECENTRALIZATION}

The structure of the EPPO has been decentralized. It has a central office which consists of: the Collegium, the permanent Council of the European Chief Prosecutor, the Deputy European Chief Prosecutor, European Prosecutors and the Administrative Director. The decentralized structure is composed of delegated European prosecutors, which are located in the member states. ${ }^{28}$ They are persons acting on behalf of the European Public Prosecutor's Office in their respective member states with special powers and under the conditions prescribed by the Regulation. They are responsible for carrying out investigations and prosecutions in proceedings initiated or taken over using the right to take over the case. They have the authority to file an indictment, make arguments at the hearing, take part in the collection of evidence, and declare remedies, in accordance with national law. Under the provisions of the Regulation, in each member state it is necessary that there is at least a delegated European prosecutor. Their maximum number, as well as the functional and territorial jurisdiction of each member state, depend on the decision of the European Chief Prosecutor. However, such a decision is made only after consultation and reaching agreement with the competent institutions of the member states. ${ }^{29}$

Delegated prosecutors are actually prosecutors at the national level of member states. They are responsible for the conduct of investigations and the prosecution of perpetrators of offenses at the expense of the financial interests of the European Union, exclusively if the acts of the offense were committed with intent, if the offense is related to the territory of two or more member states, if the commission of the criminal offense caused damage to financial interests of the European Union in the amount of at least EUR 10 million and if the criminal offense is committed within a criminal group organized for the execution of criminal offenses to the detriment of the financial interests of the European Union. The EPPO is also responsible for dealing with cases relating to offenses related to acts containing the

Art. 13. paragraph 1 of the Regulation

28 Art. 8. of the Regulation

29. Art.13. paragraph 1 and 2 of the Regulation 
aforementioned features. ${ }^{30}$ Conducting investigations and dealing with cases are the main tasks of delegated prosecutors. The results of their work will be seen only in the coming years. Practice will show how they were integrated into the national legal systems, what kind of cooperation is achieved in the host country, and with each other and what is their overall contribution to identifying, processing, and final judgments of economic crime. With successful practices, errors and experience we will be able to draw definitive conclusions about the benefits or damages of such European Union legal solutions.

\section{SHARED COMPETENCES}

The Regulation provides for a system of shared competences between the European Public Prosecutor's Office and national authorities in the suppression of criminal offenses that are detrimental to the financial interests of the European Union. In order to achieve the necessary cooperation between EPPO and national institutions, mutual exchange of information of importance for the suppression of offenses within the competence of the Office is necessary. EPPO also performs the function of the indictment before the national courts of the member states, and the Regulation also defines the relation of its provisions with the national legislation of the member states that have expressed their intention to participate in the establishment of the European Public Prosecutor's Office. Under these provisions, the national law of a member state, before whose court the European Public Prosecutor is acting, is applicable in the event that a matter is not defined by the Regulation. ${ }^{31}$ The national law of the member states, which delegated European prosecutor conducts the proceedings, shall be applied in the event that it differs in relation to the decision contained in the Regulation. In case the solutions are contained in both regulations, the provision of the Regulation shall apply. ${ }^{32}$ In this way, the solution has become suitable for the interests of the member states, whom are the most difficult to renounce sovereignty in the criminal law area.

The Regulation sets out the principle of loyalty, according to which the competent national bodies actively assist and support the investigations and prosecution carried out by the European Public Prosecutor's Office. ${ }^{33}$ The cooperation of competent authorities and institutions is also of great importance in investigative

\footnotetext{
30 Art. 22. paragraph 4 of the Regulation

31 Art. 1. and Art. 4. of the Regulation; Kostić, op. cit., note 24, p. 63

32 Art. 5. (3) of the Regulation. More about competences of the EPPO in: Mitsilegas, V.; Giuffrida, F., Raising the bar? Thoughts on the establisment of the European Public, Policy Insightes, No. 2017/39, CEPS, Brussels, 2017, p. 8

33 Art. 5. (6) of the Regulation
} 
procedures that are conducted in relation to crimes that endanger national financial interests.

Under the provisions of the Regulation, delegated public prosecutors are acting in front of the member states competent courts, on behalf of the European Public Prosecutor's Office. With regard to the disputed investigation, prosecution and indictment, they have the same powers as the national prosecutors. ${ }^{34}$ We believe that this, we can call them compromise solutions, enhances the attractiveness of EPPOs for EU member states that have not initially agreed to form this body.

\section{THE STRUCTURE OF IRREGULARITIES TO THE DETRIMENT OF THE FINANCIAL INTERESTS OF THE EUROPEAN UNION ACCORDING TO THE REPORTS OF THE EUROPEAN COMMISSION}

Article 325. of the Treaty on the Functioning of the European Union provides that the European Commission, in cooperation with the member states, each year submits to the European Parliament and the Council a report on the measures taken at the level of the member states in the field of combating fraud and other irregularities affecting the EU's financial interests. ${ }^{35}$ Based on these reports it is possible to conclude which irregularities affecting the European Union's financial interests are most often recorded by the responsible national institutions, as well as by the responsible bodies of the European Union. It has been noticed that the only similarity is the manner of committing criminal offenses, while the area in which irregularities are detected varies depending on the country on whose territory offenses occurred. Therefore, it can be said that the field of committing crimes is conditioned by various factors, such as geographic, historical, and cultural. Thus, the greatest probability that in countries using agricultural funds in order to encourage the development of agriculture, a great number of irregularities would arise in connection with the obtaining and using of these funds. A large number of irregularities in customs will most often be present in the territory of countries bordering with a non-EU country from whose territory certain goods are imported or transited. Given the specific nature of each country, it is necessary for national institutions to take adequate measures not only to detect these irregularities, but also to reduce the risk of their occurrence.

Art. 13. paragraph 1 of the Regulation

Report from the Commission to the European Parliament and the Council, Protection of the European Union's financial interests-Fight against fraud, several annual outputs 


\section{SPECIFICITY OF IRREGULARITIES IN MEMBER STATES}

The European Commission, in 2013 Report, states that a large number of irregularities affecting the European Union's financial interests are related to the evasion of payments to the EU budget, while the most frequent modus operandi was falsification of documents relevant for the determination of the amount representing the income of the European Union. In the same year, a significant number of irregularities were noted with regard to the use of funds of the European Union budget. These irregularities were observed in the context of agricultural incentive programs, and they were most present in Bulgaria, Denmark, Italy and Romania. ${ }^{36}$ During 2014, irregularities affecting the EU's financial interests have also been recorded both, in connection with failure to pay revenue, as well as in connection with the illegal acquisition and consumption of funds. The European Commission's report also states that the manner in which these crimes were committed most often was the submitting false or inaccurate documentation. ${ }^{37}$ According to the data from the 2015 Report, a large number of irregularities was recorded in the procurement procedures for solar panels. During that year, the Spanish authorities reported an increased number of irregularities in the field of cohesion policy, which resulted in greater damage to the European Union's financial interests. ${ }^{38}$

According to the data contained in the European Commission's Report for 2016, during that year, the largest number of irregularities was recorded in the procurement procedures for solar panels. There were 40 cases of suspected tax evasion related to imported goods. In this regard, for instance, a significant damage to the European Union budget was made in the 2013-2016 period when, for the purpose of tax evasion, the value of textiles and footwear imported into the European Union from the People's Republic of China through the territory of the United Kingdom was estimated to be lower than the real value. ${ }^{39}$ In addition, a large number of irregularities was discovered in the illegal spending of funds allocated to the EU's common agricultural policy. The method of committing criminal offenses during 2016 consisted mainly of using false and forged documents in the procedures for allocating these funds. Such irregularities were also revealed in connection with the decentralized management of EU funds within the agricultural

36 Report from the Commission to the European Parliament and the Council, Protection of the European Union's financial interests-Fight against fraud 2013, Annual Report pp. 10, 12. and 15

37 Report from the Commission to the European Parliaments and the Council, Protection of the European Union's financial interests-Fight against fraud 2014, Annual Report, p. 5

38 Report from the Commission to the European Parliaments and the Council, Protection of the European Union's financial interests-Fight against fraud 2015, Annual Report, pp. 20. and 27

39 Report from the Commission to the European Parliaments and the Council, Protection of the European Union's financial interests-Fight against fraud 2016, Annual Report, p. 22 
programs. ${ }^{40}$ During 2015, a large number of abuses in the procurement procedures for solar panels were also recorded, and this number increased by $36 \%$ in relation to $2014 .{ }^{41}$

During 2017, the highest number of irregularities to the detriment of the financial interests of the European Union related to the illicit consumption of the agricultural funds. The modus operandi of the offense consisted of providing false and incorrect information regarding the conditions necessary for obtaining agricultural subsidies. ${ }^{42}$

Bearing in mind great diversity in the objects and modes of fraud their detection and the collection of evidence, we're highlighting again, requires a special knowledge and skills, because criminal offenses against the financial interests of the European Union are primarily economic crimes. Sometimes, it is not sufficient to rely exclusively on the findings of responsible national authorities, such as, for example, institutions that are involved in the AFCOS network. Sometimes it is also necessary to obtain additional evidence that will be of interest for the adoption of a final judgment, but also for the return to the budget of the European Union unlawfully acquired revenues. It is therefore necessary to train public prosecutors who will handle cases against the perpetrators of criminal offenses against the financial interests of the European Union. Therefore, in addition to the specialization of public prosecutors and their deputies, of great importance is also the cooperation of the EPPO with OLAF and Europol, but also with countries that do not participate in the close cooperation procedure with regard to its establishment, as well as countries that are not members of the European Union.

\section{COOPERATION OF THE EUROPEAN PUBLIC PROSECUTOR'S OFFICE AND OLAF}

According to the provisions of Regulation 2017/1939, if the EPPO is conducting an investigation in accordance with its provisions, OLAF shall not initiate a comparative administrative investigation into these facts. However, where this is necessary, the Office may require OLAF to support or possibly supplement the activities undertaken by the Office within the limits of its powers. These activities consist mostly of providing relevant information, analysis of reports (including

\footnotetext{
40 Report from the Commission to the European Parliaments and the Council, Protection of the European Union's financial interests-Fight against fraud 2016, Op. cit. note 39, pp. 23 and 24

41 Report from the Commission to the European Parliaments and the Council, Protection of the European Union's financial interests-Fight against fraud 2015, Op. cit., note 38, p. 20

42 Report from the Commission to the European Parliament and the Council, Protection on the European Union's financial interests - Fight aganst fraud, 2017, Annual Report, p. 21
} 
forensic analysis), i.e. the application of knowledge and skills not available to the European Public Prosecutor's Office. In addition, OLAF may also provide operational support to facilitate coordination of specific measures of national institutions, and also the European Union bodies, as well as to conduct investigations and inspections, if necessary. Based on this, it can be concluded that OLAF, in relation to the Office, acts as a service for financial forensics and also as a liaison officer in relation to the national institutions and the European Union bodies, depending on the circumstances of the particular case. In addition, it also acts as a budgetary inspection of the European Union, if the Office order it to carry out certain investigations or inspections regarding suspicions of irregularities in spending of EU funds. ${ }^{43}$

In order to allow OLAF to carry out planned investigations, and in order not to duplicate the work, the European Public Prosecutor's Office has an obligation to inform OLAF in due time of the ongoing investigations. Therefore, one should provide each other with timely and adequate access to all necessary information. ${ }^{44}$

\section{COOPERATION OF THE EUROPEAN PUBLIC PROSECUTOR'S OFFICE WITH EUROPOL AND THE EUROPEAN COMMISSION}

In order to enable detection and proof of the existence of criminal offenses to the detriment of the financial interests of the European Union, the European Public Prosecutor's Office may conclude an agreement on cooperation with Europol. If necessary, EPPO may request Europol for all relevant information significant for the proceedings, as well as to request analytical support for the conduct of a specific investigation. ${ }^{45}$

The European Public Prosecutor's Office, in order to protect the financial interests of the European Union, can conclude a cooperation agreement with the European Commission. On this basis, the Office may not only provide the Commission, but also other institutions, bodies and agencies, with information of importance for taking appropriate measures in order to protect the financial interests of the European Union. To that end, the Office, in addition to the proposal for taking preventive measures, may also propose participation in the proceedings against of-

\footnotetext{
43 Art. 101, paragraphs 4 and 5 of the Regulation on implementing enchanced cooperation on the establishment of the European Public Prosecutor's Office. About relation with other EU bodies see in: Giuffrida F., The European Public Prosecutor's Office: King without Kingdom?, Research Report, No. 2017/03, CEPS, Brussels, 2017, 34

44 Art. 101. paragraphs 4 and 5 of the Regulation

45 Art.102. of the Regulation
} 
fenders for the detriment of the financial interests of the European Union. In addition, it may also inform the responsible institutions of the right to raise a claim for the return of a certain amount owed to the budget of the European Union. ${ }^{46}$ In this way, cooperation is regulated and a conflict of competence between the EPPO and EUROPOL is avoided.

\section{COOPERATION OF THE EPPO AND COUNTRIES THAT DO NOT PARTICIPATE IN THE PROCESS OF CLOSE COOPERATION IN CONNECTION WITH ITS ESTABLISHMENT AND COUNTRIES THAT ARE NOT MEMBERS OF THE EUROPEAN UNION}

Regulation 2017/1939 regulates the cooperation of the European Public Prosecutor's Office with the competent institutions of non-EU countries, as well as with other international organizations. On the basis of a special agreement, EPPO can exchange strategic information with them and request a liaison officer to work in the Office. ${ }^{47}$ Such cooperation can be established with countries that have not expressed their intention to cooperate closely in the process of establishing European Public Prosecutor's Office. Cooperation with these countries is also carried out in the same way, based on a previously concluded agreement. ${ }^{48}$ Precisely the possibility of cooperation and the posting of liaison officers to work in the Office could contribute to more efficient proving the existence of criminal offenses against the financial interests of the European Union. In this way, the door for full connection by the remaining candidate countries have been left open.

The need to establish a specific mechanism of cooperation, to verify the financial crimes, has been recognized in the legislation of Serbia, as one of the EU candidate countries. Institute of liaison officers has been established with respect to the crimes falling within the jurisdiction of the Prosecutor's Office for Organized Crime and the special departments of the Higher Public Prosecutor's Offices for the fight against corruption. In addition, in the Republic of Serbia, in accordance with the Law, it is possible to establish the financial forensic service in the aforementioned prosecutor's offices. ${ }^{49}$ Similarly, Council Regulation 2017/1939 provides for the possibility of using OLAF forensic analyzes for the purposes of inves-

\footnotetext{
46 Art. 103. of the Regulation

47 Art. 104. of the Regulation

48 Art. 105. of the Regulation

49 Art. 20-23. of the Law on Organization and Jurisdiction of State Authorities in the Suppression of Organized Crime, Terrorism and Corruption, Official Gazette of the Republic of Serbia, No. 94/2016 and 87/2018-another Law provides for the obligation and manner of delegation of liaison officers, and Art. 19. the possibility of establishing a financial forensic service at the competent prosecutor's offices
} 
tigations conducted by the European Public Prosecutor's Office. ${ }^{50}$ However, apart from specialization, for the suppression of criminal offenses against the financial interests of the European Union professional development of people involved in the detection, investigation and prosecution of perpetrators of such acts is very important. ${ }^{51}$

\section{CONCLUSIONS}

The perpetrators of criminal offenses against the EU financial interests are becoming more inventive, and the EU is making efforts, with its regulation and its overall action, to prevent and punish those violators. EPPO is one of the attempts to improve this fight. The basis for the establishment of the EPPO was created by the adoption of Regulation 2017/1939 on implementing enhanced cooperation on the establishment of the European Public Prosecutor's Office. Although a high level of agreement has been reached in many years before the establishment of such a body, it seems that skepticism is still present regarding its establishment. We believe that the European Public Prosecutor's Office is a kind of specialization of national public prosecutors. Given that they are delegated to work in the European Public Prosecutor's Office, and that they act before the competent national courts, states do not renounce their sovereignty in criminal matters. The establishment of the EPPO not only contributes to the specialization of the public prosecutors, but also raises awareness of the activities in the common interest, which is reflected in the protection of the financial interests of the European Union. The specialization of public prosecutors contributes to the improvement of cooperation with other institutions, both at the level of the European Union and with the relevant institutions of the member states and third countries. Considering the diversity of offenses in order to gather evidence of relevance to criminal proceedings, it is often necessary to possess specific knowledge and skills. Some of these skills can only be possessed by individuals who have a special experience in certain jobs. Therefore, it is a positive solution to the provisions of the Regulation, which provides that delegated public prosecutors in their work may rely on the work of financial forensics officers of the European Anti-Fraud Office. In addition, cooperation with Europol and with the institutions of countries that do not participate in the establishment of EPPO, as the non-EU countries, is of great importance for the dissemination of knowledge and experience in this fight. The manner of cooperation with the competent bodies and institutions is defined by the Regu-

\footnotetext{
50 Art. 101. (3), subitem (a) of the Regulation on implementing enchanced cooperation on the establishment of the European Public Prosecutor's Office

51 Marchuk, I., Strengthening the EU Legal and International Framework to Combat Transnational Financial Crimes, Faculty of Law, University of Copenhagen, Copenhagen, 2011, p. 50
} 
lation establishing closer cooperation between them and EPPO. Given that the manner of committing criminal acts of financial character, as well as different area in which these acts are made, is conditional upon geographical, economic, and cultural circumstances, the delegation of prosecutors from each member state is a well solution. Situation in once country is best known to its inhabitants, who are at the same time citizens of the European Union.

However, in order for the concept of the European Public Prosecutor to be widely adopted, it seems that a provision should be amended, which provides that the final decision on the indictment is not passed by a delegated European prosecutor, but the Permanent Chamber of the EPPO. Although the Regulation provides for the possibility of judicial review of procedural documents of the EPPO, it appears that the indictment is unnecessary by the Permanent Chamber. We therefore consider that such a provision is not necessary, given that the delegated public prosecutors in the member states act on behalf of the Office and that the control of the indictment in accordance with Article 6 of the European Convention on Human Rights and Article 47 of the Charter of Fundamental Rights of the European Union belongs exclusively to the court. In addition, the existence of such a provision indicates the supranational character of the EPPO, which is unacceptable for the member states. Instead, it is necessary to strengthen the awareness that the suppression of criminal offenses at the expense of the financial interests of the European Union is in fact important action of the member states in order to achieve the common interests.

\section{REFERENCES}

\section{BOOKS AND ARTICLES}

1. Giuffrida F., The European Public Prosecutor's Office: King without Kingdom?, Research Report, No. 2017/03, CEPS, Brussels, 2017

2. Hamran L.; Szabova E., European prosecutor's office-Cui bono?, New Journal of European Criminal Law, Vol. 4, Issue 1-2, 2013. pp. 40-58

3. Jelisavac Trošić, S.; Stojanović-Višić, B., EU Budget and Budget of Serbia: Impact on Serbia's Accession to the EU, Journal of Business Economics and Management, March-April 2018, year LXVI, Serbian Association of Economists, pp. 266-282, DOI:10.5937/EJOPRE1804266

4. Kostić, J.; Jelisavac Trošić, S., Digital Forensic Procedures of European Anti-Fraud Office and Protection of Personal Data, in: Duić D.; Petrašević, T. (eds.), EU and Comparative Law issues and challenges, Jean Monnet International Scientific Conference „Procedural aspects of EU law”, 06 and 07 April 2017, Josip Juraj Strossmayer University of Osijek, Faculty of Law Osijek, pp. 32-47 
5. Kostić, J., Krivičnopravna zaštita finansijskih interesa Evropske unije, Institut za uporedno pravo, Beograd, 2018

6. Marchuk, I., Strengthening the EU Legal and International Framework to Combat Transnational Financial Crimes, Faculty of Law, University of Copenhagen, Copenhagen, 2011

7. Mitsilegas, V.; Giuffrida, F., Raising the bar? Thoughts on the establisment of the European Public, Policy Insightes, No. 2017/39, CEPS, Brussels, 2017

8. Novokmet, A., European public prosecutor's office and the judicial review of criminal prosecution, New Journal of European Criminal Law, Vol. 8, No. 3, pp. 374-402, DOI: $10.1177 / 2031952517729934$

9. Stojanović, S., Razvoj sistema finansiranja Evropske unije, in: Ćirić, J. (ed.), 50 godina Evropske unije, Institut za uporedno pravo, Vlada Republike Srbije - Kancelarija za pridruživanje Evropskoj uniji, Beograd, 2007, pp. 159-185

10. Ćirić, J., Srbija i Evropski standardi u krivičnom pravu, in: Ćirić, J.; Bejatović S. (eds.), Evropske integracije i međunarodna krivičnopravna saradnja, Institut za uporedno pravo, Srpsko udruženje za krivičnopravnu teoriju i praksu, Beograd, 2011-2012, pp. 23-32

11. Šuput, J., Uspostavljanje kancelarije Evropskog javnog tužioca, Evropsko zakonodavstvo, No. 52-53, 2015, pp. $42-58$

\section{EU LAW}

1. Council Regulation 2017/1939 implementing enhanced cooperation on the establishment of the European Public Prosecutor's Office [2017] OJ L283/1

2. Directive (EU) $2017 / 1371$ of the European Parliament and of the Council on the fight against fraud to the Union's financial interests by means of criminal law, [2017] OJ L 198/29

3. Regulation (EU, Euroatom) 883/2013 of the European Parliament and of the Council concerning investigations conducted by the European Anti-Fraud Office (OLAF) and repealing Regulation (EU) No 1073/1999 of the European Parliament and of the Council and Council Regulation (Euroatom) No 1074/1999, [2013] OJ L248/1

4. Regulation (EU, Euratom) 2018/1046 of the European Parliament and of the Council on the financial rules applicable to the general budget of the Union, amending Regulations (EU) No 1296/2013, (EU) No 1301/2013, (EU) No 1303/2013, (EU) No 1304/2013, (EU) No 1309/2013, (EU) No 1316/2013, (EU) No 223/2014, (EU) No 283/2014, and Decision No 541/2014/EU and repealing Regulation (EU, Euratom) No 966/2012, [2018] OJ L193/1

5. The Convention on the protection of the European Communities financial interests, [1995] OJ C316/48

6. The Treaty on the Functioning of the European Union [2012] OJ C326

\section{NATIONAL REGULATIONS AND OTHER RESOURCES}

1. Law on Organization and Jurisdiction of State Authorities in the Suppression of Organized Crime, Terrorism and Corruption, Official Gazette of the Republic of Serbia, No. 94/2016 and 87/2018-another Law 
2. Report from the Commission to the European Parliament and the Council, Protection of the European Union's financial interests-Fight against fraud 2013, Annual Report

3. Report from the Commission to the European Parliaments and the Council, Protection of the European Union's financial interests-Fight against fraud 2014, Annual Report

4. Report from the Commission to the European Parliaments and the Council, Protection of the European Union's financial interests-Fight against fraud 2015, Annual Report

5. Report from the Commission to the European Parliaments and the Council, Protection of the European Union's financial interests-Fight against fraud 2016, Annual Report

6. Report from the Commission to the European Parliament and the Council, Protection on the European Union's financial interests - Fight against fraud, 2017, Annual Report 